\section{A ARTE COMO INVESTIMENTO: A DIMENSÃO ECONOMMICA DA PINTURA}

DIVA BENEVIDES PINHO

Săo Paulo, Nobel-Edusp, 1989,215 páginas.

\section{Por Solival Silva e Menezes}

Prof. de Economia, doutorando do Inst. de Pesquisas Econômicas da Universidade de Săo Paulo (IPE) USPI e mestrando em Finanças da EAESP/FGV.

Uma boa parte dos economistas torce o nariz ao ouvir falar de um livro que, deixando de lado os instrumentos macro e microeconómicos, as políticas de governo e outros temas comuns à Economia, vá tratar de uma questão aparentemente supérflua como as obras de arte como investimento.

$\mathrm{Na}$ verdade, não se pode esquecer que arte e, principalmente, investimentos, são uma preocupação de muita gente neste pais, notadamente, numa época de crise inflacionária como a $\mathrm{em}$ que vivemos. Além disso, o livro de Diva Pinho, que tem justamente essa preocupação, năo poderia de modo algum ser enquadrado na categoria de supérfluo, pois resgata um tema bem contemporáneo que ê a manutenção do patrimônio diante dos riscos de uma hiperinflação, ensinando que a compra de bens reais sempre foi o meio mais eficiente de garantir o poder de compra após uma crise de ascensão de preços.

$O$ livro traz, ainda, em agradáveis palavras, curiosidades históricas e recupera uma dimensão ainda pouco discutida que é a questão do valor de uma obra de arte. Não se pode esquecer que Marx e outros grandes economistas, ao tratar desse assunto, relegaram a arte à categoria especial de coisa única, de mercadoria especifica, pouco se elucubrando sobre o valor de um Matisse ou de um Di Cavalcanti.

Para Diva Pinho escrever esta obra näo foi suficiente sua condição de economista e de Professora-Titular da FEA/USP. Além disso, a prof. Pinho é pintora e sua produção inclui belíssimos quadros, com destaque para uma série sobre bóias-frias e outra de paisagens do Nordeste, além dos retratos de alguns locais já incorporados à histốna, como a Fac. de Direito da USP (Largo São Franc.) e o prédio da FEA/USP.

Entendendo de arte desde a sua concepção, elaboração e realização, a autora pode percorrer com facilidade caminhos dificeis, como contrapor arte à estrutura social, à cultura e à personalidade. Também recupera a polêmica sobre a hierarquia das artes, segundo a concepção de Hegel em seu Estétique, e discute suas dimensôes social e economica, sem se esquecer de relacionar arte à política è à tecnologia.

No segundo capítulo, Diva Pinho faz um exercício de adaptação da microeconomia tram dicional ao mercado de artes, respondendo às clássicas perguntas sobre o que, como e para quem produzir. Discute, tambem, as funçôes de oferta e demanda de pintura, com destaque para o papel dos marchands e dos críticos de arte como agentes influenciadores desse mercado, concluindo com algumas consideraçoes sobre o marketing de pintura numa concepção sistêmica e da ética própria a esse marketing.

Mais interessante, porém, é o terceiro dos quatro capitulos do livro, pois trata justamente da questăo das pinturas como investimento e diz respeito aos problemas que hoje enfrentamos de manter o capital livre dos riscos e das oscilaçôes do mercado financeiro. A autora, nesse particular, ressalta a importância da pintura como proteção contra a inflação, porém não se furta a esclarecer que se trata de um mercado bastante arriscado, embora o prazer estético seja um importante fator atenuante desses riscos.

$O$ mercado de obras de arte, tal como ocorre com o mercado financeiro, o mercado de commodities (ouro) e o mercado de moedas estrangeiras, está sujeito a especulaçōes que fazem oscilar os preços temporariamente. A autora esclarece que há um preço médio, um "preço de reserva" que sinaliza um patamar em torno do qual os detentores de uma obra de arte podem decidir se se tornam vendedores ou compradores de obras, dependendo das perspectivas de lucro que se avizinham. Esse preço e as oscilaçôes em seu entorno podem transformar pequenos proprietaxrios de obras (que as adquirem para o seu deleitel em autênticos especuladores, sobrepondo o lucro ao prazer estético.

Para os investidores previdentes, o segundo item do terceiro capítulo é absolutamente indispensavel, pois apresenta os principais fatores de risco que caracterizam esse mercado. A falsificaçāo, os modismos temporários, o roubo e a destruição podem afetar a rentabilidade de um quadro, bem como as despesas indiretas, as quaîs devem, sempre que possivel, ser incluídas no cash flow de qualquer investidor medianamente cauteloso.

O último capítulo Diva Pinho reserva para tratar do mercado de pinturas no Brasil, retratando a produção pictórica desde o Período Colonial até nossos dias, sem se esquecer da Mis$\$ a ̃ o$ Francesa, da Semana de 22 e da diversificação e explosão criativa que marcam o mercado de arte desde os anos 50. Faz, também, alguns comentarios sobre os beneficios da Lei Samey e apresenta um referencial básico de fatos econômicos, políticos e artísticos que marcaram os panoramas brasileiro e internacional desde o Renascimento, sem se esquecer do Trecento (século XIV) e do Quatrocento (século XV), épocas âureas da criaçâo artística.] 